\title{
Assessment of Antimicrobial Activity, Mode of Action and Volatile Compounds of Etlingera pavieana Essential Oil
}

\author{
Porawan Naksang ${ }^{1}\left(\mathbb{D}\right.$, Sasitorn Tongchitpakdee ${ }^{1}$, Kanjana Thumanu ${ }^{2}$, \\ Maria Jose Oruna-Concha ${ }^{3}$, Keshavan Niranjan ${ }^{3}$ and Chitsiri Rachtanapun 1,4,* \\ 1 Department of Food Science and Technology, Faculty of Agro-Industry, Kasetsart University, Bangkok 10900, \\ Thailand; porawan.n@ku.th (P.N.); sasitorn.ch@ku.th (S.T.) \\ 2 Synchrotron Light Research Institute (Public Organization), Nakhon Ratchasima 30000, Thailand; \\ kanjanat@slri.or.th \\ 3 Department of Food and Nutritional Sciences, University of Reading, Whiteknights, Reading RG6 6AP, UK; \\ m.j.oruna-concha@reading.ac.uk (M.J.O.-C.); afsniran@reading.ac.uk (K.N.) \\ 4 Center for Advanced Studied Agriculture and Food, Kasetsart University, Bangkok 10900, Thailand \\ * Correspondence: chitsiri.t@ku.th; Tel.: +66-2562-5000 (ext. 5206)
}

Academic Editors: Francesca Mancianti and Satyajit Sarker

Received: 25 May 2020; Accepted: 13 July 2020; Published: 16 July 2020

\begin{abstract}
Etlingera pavieana (Pierre ex Gagnep.) R.M.S. is a rhizomatous plant in the Zingiberaceae family which could be freshly eaten, used as a condiment or as a traditional remedy. Our work investigated the chemical composition and antimicrobial activity of the E. pavieana essential oils extracted from the rhizome (EOEP). We extracted the EOEP from the rhizome by hydrodistillation and analyzed the chemical composition by headspace solid-phase microextraction coupled with gas chromatography/mass spectrometry (HS-SPME-GC/MS). A total of 22 volatile compounds were identified where trans-anethole $(78.54 \%)$ and estragole $(19.36 \%)$ were the major components in the EOEP. The antimicrobial activity of EOEP was evaluated based on the minimum inhibitory concentration (MIC) and the minimum bactericidal concentration (MBC) values using the broth dilution method and enumerating cell death overtime. Our work shows that the EOEP exhibits potent antibacterial activity against foodborne pathogenic Gram-positive bacteria, namely Bacillus cereus, Staphylococcus aureus and Listeria monocytogenes in the range of $0.1-0.3 \%(v / v)$. We further investigated the mechanism of EOEP inhibition using Synchrotron Fourier transformation infrared (FTIR) microspectroscopy. Here, we show significant differences in DNA/nucleic acid, proteins and cell membrane composition in the bacterial cell. To conclude, EOEP exhibited antimicrobial activity against foodborne pathogens, especially the Gram-positive bacteria associated with ready-to-eat (RTE) food and, thus, has the potential to serve as a natural preservative agent in RTE products.
\end{abstract}

Keywords: Etlingera pavieana; essential oil; antimicrobial activity; foodborne pathogens; mode of action

\section{Introduction}

Etlingera pavieana (Pierre ex Gagnep.) R.M.S., Raew-hawm in Thai, is an aromatic plant in the genus Etlingera belonging to the Zingiberaceae, or the ginger family. It is widely distributed in south-eastern Thailand and the Cardamon Mountains in Cambodia. The rhizome of E. pavieana, as shown in Figure 1, has been used as a traditional medicine to heal symptoms, such as nausea, fever and flatulence. It is also used as a diuretic [1,2]. In a local Thai food, known as Moo Lieng noodle, which is a traditional dish in Chantaburi and Trad province, it is used as the main ingredient. There is some research evidence to demonstrate its antimicrobial activity against Mycobacterium tuberculosis, Escherichia coli, Staphylococcus aureus, Bacillus cereus and Listeria monocytogenes, and it has also been shown to possess antioxidant, 
anti-inflammatory and anticancer activities in human breasts [2-5]. However, its bioactivities are largely varied, depending upon factors, such as plant parts, extraction method employed and the solvent used [4].
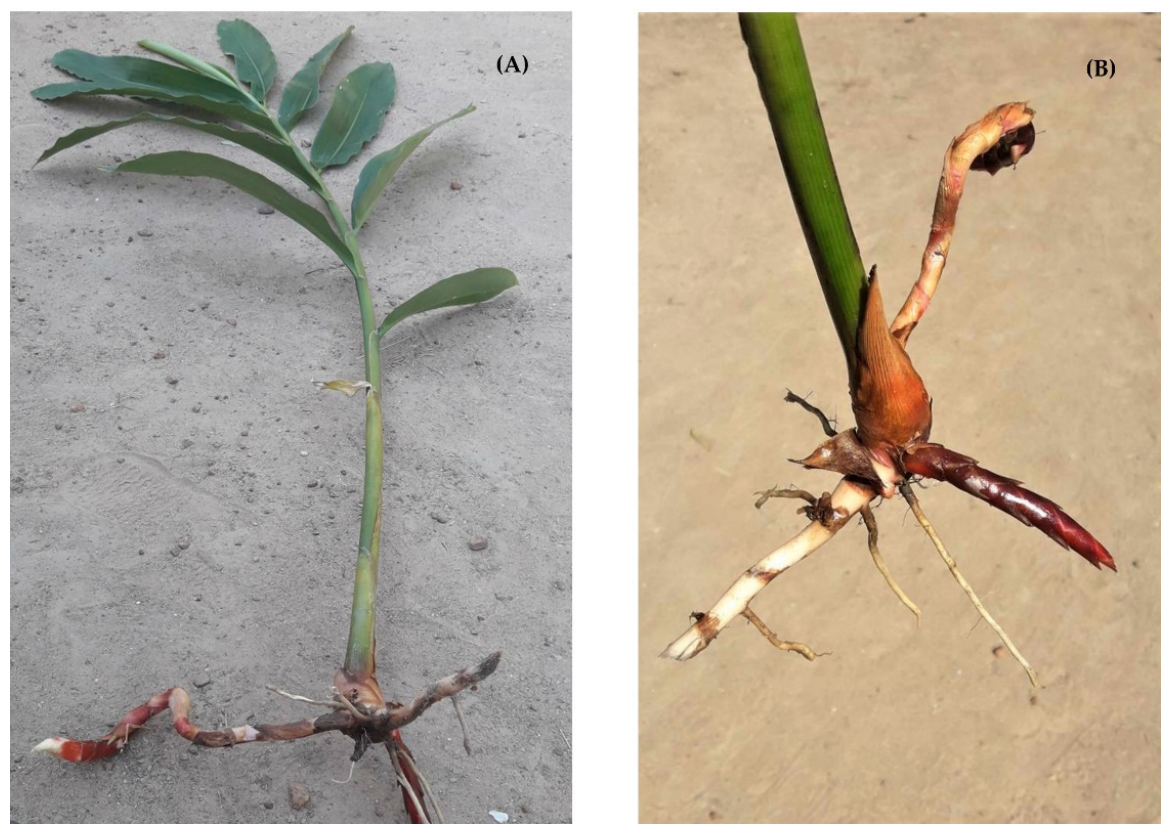

Figure 1. Photographs of Etlingera pavieana (Pierre ex Gagnep.) R.M.Sm. plant (A) and E. pavieana rhizome (B).

A number of recent studies on the volatile composition of Etlingera spp. focus on the essential oil obtained either by steam distillation or hydrodistillation, as well as others by basic extraction techniques involving the use of organic solvents. However, there are relatively few studies on the volatile compounds of Zingiberaceae extracts obtained using alternative methods, such as headspace solid-phase microextraction coupled with gas chromatography/mass spectrometry (HS-SPME-GC/MS. The HS-SPME-GC/MS is increasingly used for fast and automatic extraction coupled with a high-throughput analysis of a large number of volatile compounds in a single step without involving the use of solvents [6,7]. Despite many traditional uses and medicinal claims of different species of Etlingera, very few scientific studies have focused on the essential oil. Particularly, the mode of action of the essential oils was much less mentioned. As far as we know, no information is available on the investigation into these antimicrobial mechanisms using Synchrotron FTIR microspectroscopy. Thus, this research aimed to extract the volatile compounds from E. pavieana analyze the antimicrobial activity of the extract and investigate the mechanism of its action against pathogenic bacteria present in ready-to-eat (RTE) products so that the extract can be used as a natural food preservative.

\section{Results and Discussion}

\subsection{Yield Percentage and Analysis of the Volatile Compounds from the Rhizome of E. pavieana Essential Oils (EOEP)}

The EOEP obtained after hydrodistillation shows a light yellow color. The yield percentage of EOEP was $0.13 \%(v / w$ on fresh weight basis), which is slightly lower than the products obtained from other rhizomes of Etlingera spp., which range between 0.28 and $0.70 \%$ ( $v / w$ on dry weight basis) $[2,8]$. However, this is much greater than the estimated oil yield on a fresh weight basis, which is at $0.019-0.047 \%(v / w)$ [9].

The volatile composition of the EOEP from rhizome is shown in Table 1. Twenty-two compounds have been identified, representing $99.94 \%$ of the total oil composition. This amount comprised 
2 phenylpropanoids (97.90\%), 11 monoterpenes (1.55\%), 7 oxygenated monoterpenes $(0.40 \%)$ and 2 sesquiterpenes $(0.09 \%)$, respectively. Trans-anethole $(78.54 \%)$ and methyl chavicol or estragole $(19.36 \%)$ were the major compounds (Figure 2$)$, followed by $\beta$-myrcene $(0.84 \%)$, camphene $(0.17 \%)$, pinocarvone $(0.15 \%)$, camphor $(0.12 \%)$ and $\alpha$-pinene $(0.12 \%)$, respectively. This result is in accordance with Ud-Daula and Basher [10], who reported that phenylpropanoids (non-terpenic compounds) were the main chemical group in the rhizome essential oils of the E. pavieana, Etlingera brevilabrum (Valeton) R.M.Sm., Etlingera cevuga (Seem.) R.M.Sm., Etlingera linguiforme (Roxb.) R.M.Sm., Etlingera littoralis (J. Koenig) Giseke and Etlingera punicea (Roxb.) R.M.Sm. Among the phenylproponoids, trans-anethole (48.6\%) was the major compounds in the essential oil of E. pavieana, and methyl chavicol dominated the rhizome oil of E. punicea (95.75\%) and E. linguiforme (49.9\%), respectively $[2,11,12]$. In the work of Tachai [2], who analyzed the hydrodistilled essential oil from dried rhizomes of E. pavieana in the Chantaburi province, Thailand, trans-anethole $(48.6 \%), p$-anisaldehyde $(13.8 \%)$, $\delta$-cadinene $(7.2 \%)$, trans-methyl isoeugenol $(2.7 \%)$ and $\alpha$-cadinol $(2.4 \%)$ were the major components. Furthermore, a series of phenylpropanoids, such as 4-methoxycinnamaldehyde, 4-methoxycinnamyl $p$-coumarate, 4-methoxycinnamyl alcohol and $p$-coumaric acid, have been extracted from the rhizome of E. pavieana from Thailand [3,5]. In addition, terpenes (monoterpene hydrocarbons and sesquiterpene hydrocarbons) and terpenoids (oxygenated monoterpenes and oxygenated sesquiterpenes) were found in small proportions in the essential oil of E. pavieana [2,10]. However, those terpinic compounds are abundant in most Etlingera species, including E. brevilabrum, Etlingera elatior (Jack) R.M.Sm., Etlingera fimbriobracteata (K.Schum.) R.M.Sm., E. megalocheilos (Griff.) A.D. Poulsen, comb. nov. and Etlingera sayapensis A.D. Poulsen and Ibrahim [8,13-16]. Monoterpene hydrocarbons, such as $\alpha$-pinene, camphene, $\beta$-myrcene, $\mathrm{D}$-Limonene and $\beta$-ocimene, were found in high percentages in the essential oil, in particular, in the oils from leaves $[10,12,13]$. Comparing the components of essential oils from Etlingera species, the chemical compositions are influenced by the plant species and parts, sources and the methods of preparation $[13,17]$.

Table 1. Volatile compounds of EOEP analyzed by HS-SPME-GC/MS.

\begin{tabular}{|c|c|c|}
\hline Compounds & LRI $^{a}$ & $\%$ Area $^{b}$ \\
\hline Monoterpenes (Total) & \multicolumn{2}{|c|}{1.55} \\
\hline (-)- $\alpha$-Pinene & 944 & 0.12 \\
\hline Camphene & 948 & 0.17 \\
\hline$\beta$-Myrcene & 989 & 0.84 \\
\hline$(+)$-3-Carene & 1014 & 0.07 \\
\hline$\alpha$-Phellandrene & 1014 & 0.01 \\
\hline o-Cymene & 1034 & 0.01 \\
\hline$p$-Cymene & 1034 & 0.01 \\
\hline D-Limonene & 1039 & 0.15 \\
\hline$\beta$-Ocimene & 1041 & 0.15 \\
\hline$\delta$-Terpinene & 1067 & 0.01 \\
\hline Bornyl acetate & 1300 & 0.01 \\
\hline \multicolumn{2}{|c|}{ Oxygenate monoterpenes (Total) } & 0.40 \\
\hline Eucalyptol & 1041 & 0.01 \\
\hline L-Fenchone & 1101 & 0.01 \\
\hline Camphor & 1163 & 0.12 \\
\hline Pinocarvone & 1163 & 0.15 \\
\hline endo-Borneol & 1184 & 0.04 \\
\hline Terpinen-4-ol & 1193 & 0.03 \\
\hline$\alpha$-Terpineol & 1204 & 0.04 \\
\hline Phenylpropanoids (Total) & \multicolumn{2}{|c|}{97.90} \\
\hline Methyl chavicol (Estragole) & 1210 & 19.36 \\
\hline trans-Anethole & 1300 & 78.54 \\
\hline Sesquiterpenes (Total) & \multicolumn{2}{|c|}{0.09} \\
\hline$\alpha$-Copaene & 1402 & 0.01 \\
\hline Alloaromadendrene & 1496 & 0.08 \\
\hline Total & & 99.94 \\
\hline
\end{tabular}

a Linear Retention Indices (LRI) on DB-5 MS capillary column. ${ }^{\mathrm{b}}$ Relative area (Percent of total peak area for each sample). 


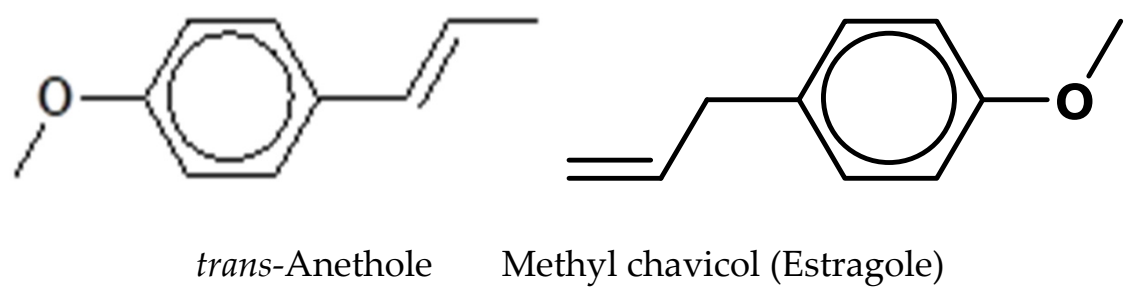

Figure 2. Structures of the main compounds identified in EOEP.

\subsection{Determination of the MIC and MBC of EOEP}

The antimicrobial activity of EOEP from the rhizome against foodborne microorganisms was assessed by MIC and MBC values investigated by broth dilution assay, as shown in Table 2. The results show that EOEP has a stronger antimicrobial activity against Gram-positive bacteria than Gram-negative bacteria. The MIC and MBC values against Gram-positive bacteria range between 0.02 to $0.03 \%(v / v)$ and 0.10 to $0.30 \%(v / v)$, respectively, while the MIC and MBC values against most Gram-negative bacteria and lactic acid bacteria are $5 \%(v / v)$ or greater. Thus, this EOEP is not strongly effective against Gram-negative bacteria. Amongst the bacteria tested, L. monocytogenes strain 108 and Scott A were found to be most sensitive strains with the MIC and MBC values of $0.02 \%(v / v)$ and $0.10 \%$ $(v / v)$, respectively, followed by $B$. cereus, which gave values of $0.02 \%$ and $0.15 \%(v / v)$, respectively. The antimicrobial activity of the E. pavieana essential oil has been reported in few studies. There was only one report on the biological activities of the E. pavieana essential oil and, although it showed cytotoxic activity on human small-cell lung cancer (NCI-H187) cells with an $\mathrm{IC}_{50}$ value of $31.69 \mu \mathrm{g} / \mathrm{mL}$, it was inactive against Mycobacterium tuberculosis [18]. From our previous publication, various solvent extracts of E. pavieana, including ethanol, acetone, dichloromethane, ethyl acetate, petroleum ether and hexane, had antibacterial activity against Gram-positive bacteria (Bacillus cereus, B. subtilis, Staphylococcus aureus and Listeria monocytogenes) and Gram-negative bacteria (Escherichia coli, Pseudomonas aeruginosa, Vibrio parahaemolyticus and Salmonella typhimurium) [4]. Comparing the antimicrobial activity of the Etlingera essential oils, the essential oils from E. elatior, Etlingera fulgens, Etlingera maingayi, E. punicea and Etlingera rubrostriata had antibacterial activity against Gram-positive bacteria, namely B. cereus, Micrococcus luteus and S. aureus [11,19,20]. Moreover, the essential oil of E. elatior flowers and E. punicea had antifungal activity against Candida albicans [11,20]. However, those essential oils were ineffective against Gram-negative bacteria, including E. coli, Pseudomonas aeruginosa, Salmonella albany and Salmonella Choleraesuis. These reports correspond to the findings we have presented above. It has been generally reported that Gram-negative bacteria are more resistant to antimicrobial agents due to the lipopolysaccharide layer on the outer membrane of Gram-negative bacteria being highly hydrophilic. This acts as a strong barrier against hydrophobic molecules, which are the majority of the antimicrobial agents. In contrast, the cell walls of the Gram-positive bacteria only consist of thick peptidoglycan, which make the bacteria more susceptible to attack by the antibacterial agents [13,20-22]. Interestingly, lactic acid bacteria, which are mostly Gram-positive, are more resistant to EO than the other Gram-positive members [23-26]. This effect may be due to the surface of the lactic acid bacteria, including Lactobacillus spp., which are able to provide intrinsic resistance to some antibacterial agents [23]. 
Table 2. The minimal inhibitory concentration (MIC) and minimal bactericidal concentration (MBC) values of EOEP against foodborne microorganisms determined by broth dilution method.

\begin{tabular}{ccc}
\hline Tested Bacteria & MIC $(\%$ v/v) & MBC $(\% v / v)$ \\
\hline Gram-Positive Bacteria & & \\
Bacillus cereus & 0.02 & 0.15 \\
Staphylococcus aureus & 0.03 & 0.15 \\
Listeria monocytogenes 101 & 0.02 & 0.15 \\
Listeria monocytogenes 108 & 0.02 & 0.10 \\
Listeria monocytogenes V7 & 0.02 & 0.30 \\
Listeria monocytogenes Scott A & 0.02 & 0.10 \\
Gram-negative bacteria & & \\
Escherichia coli & 5.00 & 5.00 \\
Pseudomonas aeruginosa & $>5.00$ & $>5.00$ \\
Salmonella Typhimurium & $>5.00$ & $>5.00$ \\
Lactic acid bacteria & & \\
Lactobacillus plantarum 541 & $>5.00$ & $>5.00$ \\
Lactobacillus plantarum 844 & $>5.00$ & $>5.00$ \\
Pediococcus cerevisiae & $>5.00$ & $>5.00$ \\
Leuconostoc mesenteroides & $>5.00$ & $>5.00$ \\
\hline
\end{tabular}

MIC = the lowest concentration of antimicrobial concentration required to inhibit the visible growth of bacteria tested in the test tube. $\mathrm{MBC}=$ the lowest concentration of antimicrobial concentration required to diminish at least $99.9 \%$ (3 Log reduction) of the initial bacterial amount at $24 \mathrm{~h}$. The experiment was carried out in triplicate and the modal values are shown.

\subsection{Enumeration Cell Death Over Time by Time-Kill Curve}

Time-kill assay of EOEP against the tested bacterial species was performed to determine the response on the growth pattern. Based on the MIC and MBC values, six concentrations of EOEP were tested against foodborne pathogenic Gram-positive bacteria, including B. cereus, S. aureus and L. monocytogenes, at an initial concentration of ca. $3 \log \mathrm{CFU} / \mathrm{mL}$. The bacterial viable cells were enumerated over time to investigate their response to the antimicrobial agent, as shown in Figure 3. The bacteriostatic (the concentration where the bacterial culture remains constant) and bactericidal (the concentration where the bacteria dies at no viable count in 18h) concentrations can be determined from Figure 3 [27]. All bacterial strains grew well in the control sample (non-selective media without the addition of EOEP). The cell numbers of B. cereus and S. aureus in the control (TSB without EOEP) reached $9 \mathrm{Log} \mathrm{CFU} / \mathrm{mL}$ in $12 \mathrm{~h}$, as shown in Figure 3A,B. When $0.01 \%$ EOEP was added to the broth medium, B. cereus cells grew to $9 \mathrm{Log} \mathrm{CFU} / \mathrm{mL}$ in $12 \mathrm{~h}$, which was similar to the control. In $0.03 \%$ EOEP, the bacterial cell count remained constant at ca. $2 \log \mathrm{CFU} / \mathrm{mL}$ for $12 \mathrm{~h}$ and then increased to $8 \mathrm{Log}$ $\mathrm{CFU} / \mathrm{mL}$ after $18 \mathrm{~h}$. On the other hand, bactericidal effect was detected at an EOEP concentration of $0.05 \%$ as the number of cells gradually reduced to undetectable levels within $18 \mathrm{~h}$. Furthermore, at a concentration of $0.15 \%$, the number of $B$. cereus cells became undetectable within $12 \mathrm{~h}$. The response of S. aureus to 0.01 and $0.03 \%$ EOEP was similar to B. cereus, as shown in Figure 3B. In the case where $0.05 \%$ EOEP was applied, it showed a bacteriostatic effect, as seen in the fact that the cell numbers remained constant at ca. $2 \log \mathrm{CFU} / \mathrm{mL}$ throughout the study. At 0.10 and $0.15 \%$, EOEP became bactericidal, and the number of cells reduced to undetectable amounts within 24 and $18 \mathrm{~h}$, respectively. The response of L. monocytogenes to EOEP was more sensitive than other species, as it showed bacteriostatic effect at $0.03 \%$ EOEP, and became bactericidal at $0.05 \%$ EOEP. The listerial cell was completely inactivated at $0.10 \%$ EOEP within $24 \mathrm{~h}$, as shown in Figure 3C. In summary, time-kill curves revealed the dynamic response of the bacterial cells on the growth pattern at an EOEP concentration of $0.01 \%$, which showed an inhibitory effect against B. cereus, S. aureus and L. monocytogenes Scott A. At a concentration of $0.03 \%$, EOEP showed bacteriostatic effect and, at $0.1 \%$ or greater, EOEP showed lethal effect. 

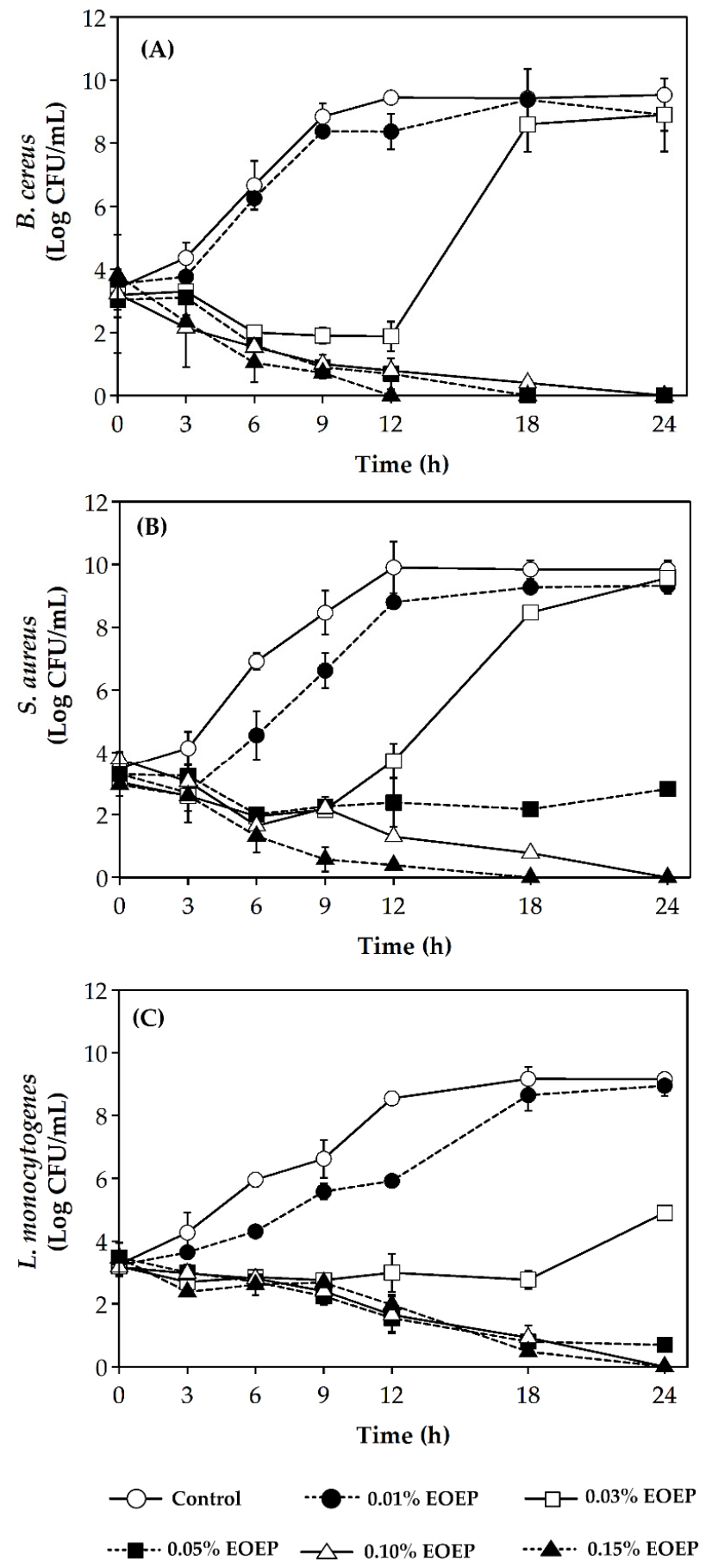

Figure 3. Killing curves for various concentrations of EOEP against B. cereus (A), S. aureus (B) and L. monocytogenes Scott A (C).

Though reports on the antimicrobial activity of EOEP are limited, its inhibitory activity against test bacteria could be attributed to the presence of bioactive compounds, mainly trans-anethole and methyl chavicol (estragole), as previously reported [11,21,28-30]. Trans-Anethole at a concentration of $75 \mu \mathrm{g} / \mathrm{mL}$ showed clear inhibition of the growth of S. aureus at inoculum level of $10^{5}$ cells/plate [28]. Estragole had a strong inhibitory effect against Pseudomonas syringae in the liquid culture assay throughout $24 \mathrm{~h}$. The effectiveness of estragole was stronger than eugenol $>$ methyl-eugenol $>$ cinnamaldehyde, respectively [29]. Moreover, the antibacterial activity of estragole is comparatively higher than that of trans-anethole [30]. The estragole-rich oil exhibited MICs of 3.7, 6.7 and $13.2 \mathrm{mg} / \mathrm{mL}$ against 
C. albican, S. aureus and E. coli, respectively, while trans-anethole-rich oil showed a MIC of $1.8 \mathrm{mg} / \mathrm{mL}$ against $C$. albican. In contrast, the antioxidative activity of estragole is comparatively less than trans-anethole [31]. Nonetheless, it has been shown to carry antioxidative activity. Both trans-anethole and methyl chavicol (estragole) have shown both antioxidant and antimicrobial activities, but very little is known about their modes of action against target microorganisms.

\subsection{Determination of the Modes of Action of EOEP on B. cereus Using Synchrotron FTIR Microspectroscopy}

\subsubsection{Assessment of Antimicrobial Action of EOEP Using Synchrotron FTIR Microspectroscopy}

The effect of EOEP on the cellular components of B. cereus was investigated by Synchrotron FTIR microspectroscopy. FTIR spectra of cells treated with $0.1 \%$ EOEP for 0,6 and $12 \mathrm{~h}$ are shown in Figure 4A. The FTIR spectra for most bacteria were divided into four regions comprising the fatty acid in the cell (Region I; peak from 3000 to $2800 \mathrm{~cm}^{-1}$ ), the amide groups from proteins and peptides (Region II; peak from $1700-1500 \mathrm{~cm}^{-1}$ ), the mixed region governed by fatty acids, proteins and phosphate-carrying molecules (Region III; peak from $1500-1200 \mathrm{~cm}^{-1}$ ) and nucleic acid, DNA and RNA (Region IV; peak from 1200-1000 $\mathrm{cm}^{-1}$ ) [32]. The spectra obtained for B. cereus corresponded to those previously described [33,34]. Strong absorption units obtained for all regions, demonstrating the main components of a cell. To assess the detailed structure of the FTIR spectra and characterize the related variations among bacterial FTIR spectra, the second derivative was analyzed, as shown in Figure 4B,C. The representative FTIR band assignments of biomolecule groups are shown in Table 3.
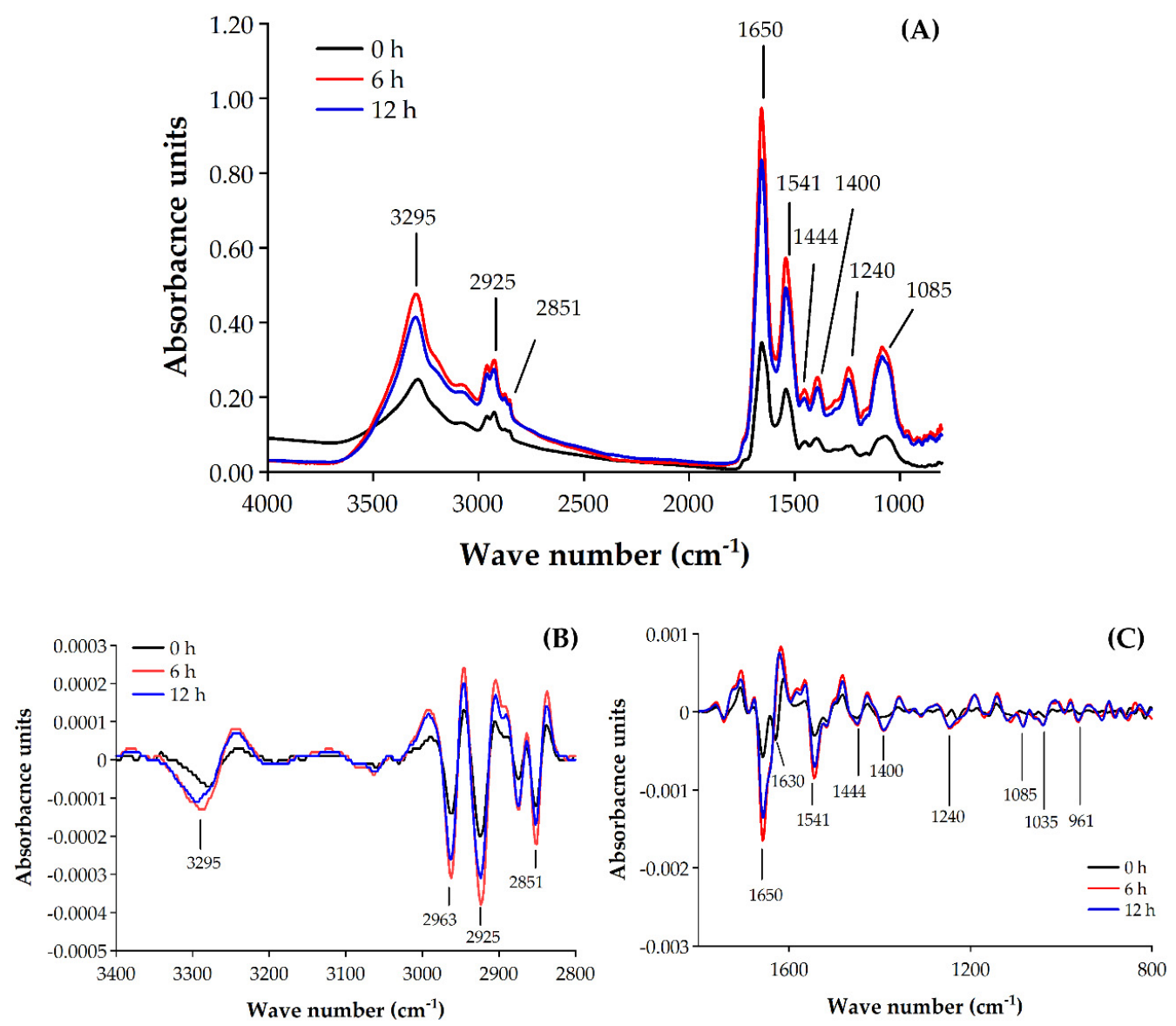

Figure 4. FTIR spectra region of B. cereus treated with $0.1 \%$ EOEP for 0,6 and $12 \mathrm{~h}(\mathbf{A})$ and second derivative transformation spectra of $B$. cereus treated with $0.1 \%$ EOEP for 0,6 and $12 \mathrm{~h}(\mathrm{~B}, \mathrm{C})$. Triplicate experiments were averaged. 
Table 3. Band area $\left(\times 10^{-3} \mathrm{~cm}^{-1}\right)$ and band area changes of $B$. cereus treated with $0.1 \% v / v$ of EOEP.

\begin{tabular}{|c|c|c|c|c|c|}
\hline \multirow{2}{*}{$\begin{array}{c}\text { Wave } \\
\text { Number }\left(\mathrm{cm}^{-1}\right)\end{array}$} & \multirow{2}{*}{ Possible Biomolecule Contributors } & \multicolumn{3}{|c|}{ Contact Time } & \multirow{2}{*}{ References } \\
\hline & & $0 \mathrm{~h}$ & $6 \mathrm{~h}$ & $12 \mathrm{~h}$ & \\
\hline 3295 & Amid A in Proteins & $246.37 \pm 0.01 b$ & $475.86 \pm 0.06 a$ & $414.12 \pm 0.01 \mathrm{a}$ & {$[36,38]$} \\
\hline 2851 & Fatty acids & $107.39 \pm 0.00 \mathrm{~b}$ & $190.44 \pm 0.02 \mathrm{a}$ & $177.77 \pm 0.01 \mathrm{a}$ & [35-37] \\
\hline 1650 & Proteinaceous content of cell & $340.63 \pm 0.02 c$ & $938.52 \pm 0.10 \mathrm{a}$ & $808.40 \pm 0.05 b$ & {$[32,37,40]$} \\
\hline 1630 & Proteinaceous content of cell & $272.01 \pm 0.09 c$ & $609.91 \pm 0.07 a$ & $514.76 \pm 0.03 b$ & {$[32,37,41]$} \\
\hline 1400 & Cell membrane (amino acids, fatty acids) & $89.56 \pm 0.01 b$ & $244.34 \pm 0.03 a$ & $215.35 \pm 0.01 \mathrm{a}$ & {$[36,37,44]$} \\
\hline 1240 & Phosphodiesters in nucleic acid & $69.24 \pm 0.01 b$ & $277.30 \pm 0.03 a$ & $245.85 \pm 0.01 \mathrm{a}$ & {$[37,45]$} \\
\hline 1085 & DNA and RNA, phospholipids & $92.20 \pm 0.00 \mathrm{~b}$ & $334.54 \pm 0.04 a$ & $308.73 \pm 0.01 a$ & {$[32,37,45]$} \\
\hline
\end{tabular}

Values are given as mean \pm standard deviation. $a-b$ Different letters in the same row indicate significant differences between the means obtained in Duncan's test $(p \leq 0.05)$.

The FTIR micrographs revealed the change in cellular components in the spectral intensity at the dominant peaks at 3295, 2925, 2851,1657, 1541,1444,1400, 1240 and $1085 \mathrm{~cm}^{-1}$. Overall, the cells show significant changes after being treated with EOEP for 6-12 h $(p \leq 0.05)$. After cells were treated for $6 \mathrm{~h}$, the most apparent change occurs at the DNA/nucleic acid region where the absorptions of bands 1240 and $1085 \mathrm{~cm}^{-1}$ increase about 4- and 3-fold, respectively. The band at $1240 \mathrm{~cm}^{-1}$ represented the phosphate group $(\mathrm{P}=\mathrm{O})$ asymmetric stretching of phosphodiesters in phospholipids and RNA $[35,36]$ and $1085 \mathrm{~cm}^{-1}$ represented a phosphate symmetric stretching in DNA, RNA and phospholipids [36,37]. We also observed a 2-fold increase in the Amide I of $\alpha$-helical structures $\left(1650 \mathrm{~cm}^{-1}\right)$, the Amide I of $\beta$-pleated sheet structures $\left(1630 \mathrm{~cm}^{-1}\right)$ and the Amide II $\left(1541 \mathrm{~cm}^{-1}\right)$ region after 6 and $12 \mathrm{~h}$ of treatment, respectively $[35,37]$. Moreover, we hypothesized a major disruption in the cell membrane due to the change in the two absorbance bands at $1400 \mathrm{~cm}^{-1}$ and $1444 \mathrm{~cm}^{-1}$, with the former attributed to the symmetric stretching of the COO-group in amino acids and fatty acids in the cell membrane [36] and the deformation of the $\mathrm{CH}_{2}$ of lipids and fatty acids in the cell membrane [35]. The increase in the spectra at 1650,1541, 1444, 1400, 1240 and $1085 \mathrm{~cm}^{-1}$ suggests a leakage of cellular components. These changes generally reflect changes in the cell membrane and the leakage of the nucleic acids into the solvent. These results showed the most substantial cellular biomolecule changes in phosphodiesters in nucleic acid, including DNA and RNA, followed by cell membrane and proteinaceous substances after being treated with EOEP for $6 \mathrm{~h}$.

\subsubsection{Principal Component Analysis (PCA) of the FTIR Spectra from B. cereus Treated with EOEP}

We conducted PCA to justify this multivariate data set and differentiate changes between untreated cells and treated cells. Here, we showed clear data segregations between untreated cells and treated cells of the scores for the PC1 (variability; 60\%) and PC2 (variability; 23\%), as shown in Figure 5. The PCA score plot shows that spectra from a cell treated with $0.1 \%$ EOEP for 0,6 and $12 \mathrm{~h}$ on B. cereus can be clustered separately along PC1 and PC2. Moreover, a grouping of the spectra represents significant differences between untreated $(0 \mathrm{~min})$ and treated cells $(6$ and $12 \mathrm{~h})$ that can be correlated with changes in the molecular composition of B. cereus, including fatty acid $\left(2925 \mathrm{~cm}^{-1}\right)$, protein $\left(1630 \mathrm{~cm}^{-1}\right)$, and mixed region, which characterizes the cell membrane and DNA/nucleic acids (1240 and $\left.1085 \mathrm{~cm}^{-1}\right)$. The PCA results correspond to the time-kill assay, as previously described, as the EOEP at concentration $0.1 \%$ showed bactericidal effect against $B$. cereus within $6 \mathrm{~h}$ and continuously throughout $12 \mathrm{~h}$. Interestingly, the negative and positive spectral variations indicated by the PC1 and PC2 loading plots that were oppositely correlated to each other at $1630 \mathrm{~cm}^{-1}$ may indicate a higher level of amide I of $\beta$-pleated sheet structures in the proteinaceous content of treated cells compared to untreated cells. Additionally, the oppositely correlated PC1 and PC2 at 1240 and $1085 \mathrm{~cm}^{-1}$ may reflect considerable level of nucleic acids, DNA and RNA of the treated and untreated cells. Our findings reveal the mode of action of the EOEP targeted on the phosphodiester of the nucleic acids, including DNA and RNA and the proteinaceous substances of cells, in particular, amide I. 

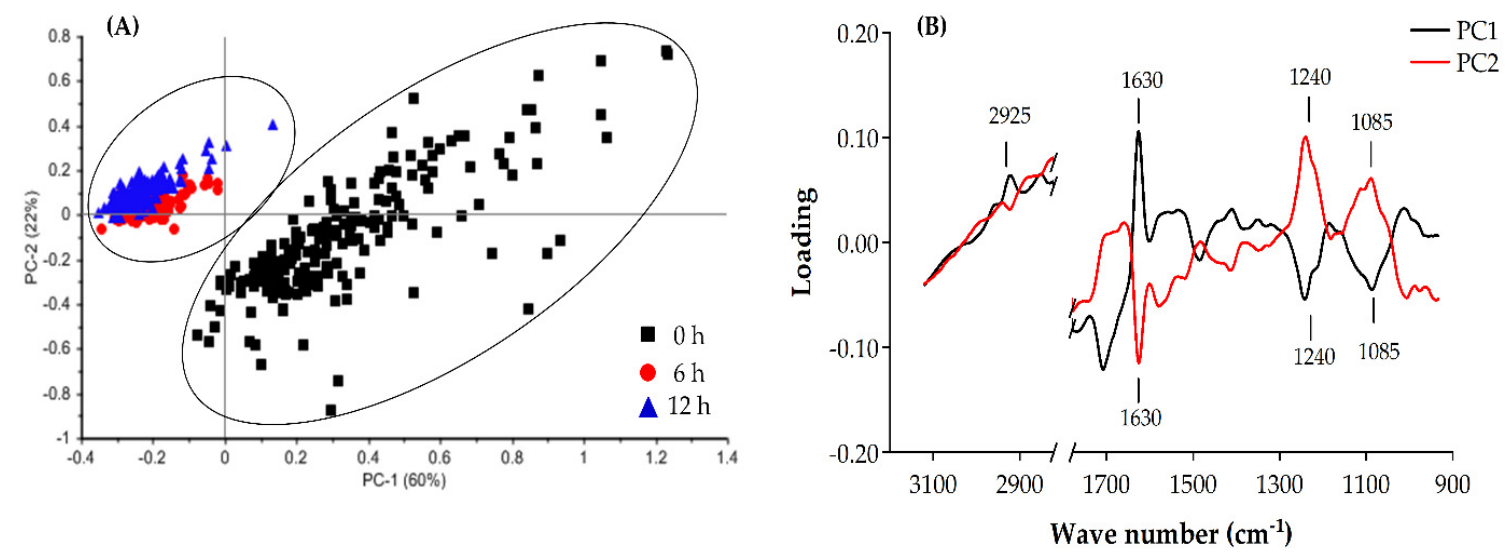

Figure 5. Scores plots (A) and loading plots (B) from PCA of the overall spectra data for B. cereus treated with $0.1 \%$ EOEP for 0,6 and $12 \mathrm{~h}$.

\section{Materials and Methods}

\subsection{Plant Material}

The E. pavieana was cultivated in a commercial local farm in the Trad province, Thailand. The plant was collected and identified by an expert herbalist. The whole plant of E. pavieana was harvested in August 2015. The fresh rhizomes of E. pavieana were washed to remove soil and chopped into small pieces. The chopped rhizomes $(100 \mathrm{~kg})$ were fed into a vertical hydrodistillation machine (HVAC Engineering Co. Ltd., Pathumthani, Thailand) for $10 \mathrm{~h}$. The essential oil was stored at $-30^{\circ} \mathrm{C}$ in an airtight container for further use. The total amount of essential oil was recorded. The yield percentage was calculated on a fresh weight basis.

\subsection{Characterization of Chemical Composition of EOEP}

The volatile compositions of EOEP from the rhizome were characterized by a headspace solid-phase microextraction system (HS-SPME) using a 50/30 $\mu$ m divinylbenzene (DVB)/ polydimethylsiloxane (PDMS) fiber (Supelco, Bellefonte, PA, USA), according to the method of Morales-Soto et al. [5] and Saoudi et al. [6] with some modifications. The EOEP, $0.5 \mathrm{~g}$, was weighed and $4.5 \mathrm{~mL}$ of ethyl ether was added to a SMPE vial of $15 \mathrm{~mL}$ fitted with a screw cap. After equilibration at $40{ }^{\circ} \mathrm{C}$ for $10 \mathrm{~min}$, the fiber was exposed to the headspace above the sample for $30 \mathrm{~min}$. The sample was kept under stirring at $40^{\circ} \mathrm{C}$ and desorbed for $20 \mathrm{~min}$ in the GC injector at $250^{\circ} \mathrm{C}$. Analysis was done in triplicate. The GC-MS analysis of SPME extracts was carried out as described by Morales-Soto et al. [5]. Briefly, the volatile compounds were identified by comparison with mass spectra from NIST/EPA/NIH databases and confirmed in many cases by the comparison of their retention indices with databases (http://www.pherobase.com) and the ADAMS library. To confirm the identification, the linear retention index (LRI) was calculated for each volatile, using the retention times of a homologous series of C6-C25n-alkanes. Semiquantitative determinations were expressed as the percentage of total peak area within each sample.

\subsection{Microorganisms Preparation}

In total, we tested 17 strains of foodborne microorganisms. These include Gram-positive bacteria, namely B. cereus TISTR687, S. aureus TISTR1466, L. monocytogenes strain 101, 108, V7 and Scott A, lactic acid bacteria, namely L. pentosus TISTR920, L. plantarum strains TISTR541, TISTR844 and TISTR850, L. mesenteroides TISTR053 and P. cerevisiae and, finally, Gram-negative bacteria, namely E. coli TISTR780, S. enterica serotype Typhimurium ATCC13311 and P. aeruginosa TISTR781. For the culture preparation, B. cereus, S. aureus, S. Typhimurium and P. aeruginosa were grown in TSB at $37^{\circ} \mathrm{C}$, except for B. cereus, which was cultured at $30^{\circ} \mathrm{C}$. Listeria spp. was grown in TSB containing $0.6 \%$ yeast extract (YE) at $37^{\circ} \mathrm{C}$ 
and lactic acid bacteria were grown in MRS broth. The culture was then subjected to two successive $24 \mathrm{~h}$ and $18 \mathrm{~h}$ transfers before use.

\subsection{Determination of Antimicrobial Activity}

\subsubsection{MIC and MBC Assay}

The broth dilution method was used for determining both the MIC and MBC of the EOEP against all strains of tested bacteria. This method was used as modified from Sukmark et al. [46]. Test tubes containing $5 \mathrm{~mL}$ of each bacterium (4-5 Log CFU/mL) and double strength Mueller-Hinton broth (MHB; Merck, Darmstadt, Germany), MHBYE for Listeria spp. or MRS broth for lactic acid bacteria were mixed to a single concentration in either EOEP or sterilized deionized (DI) water to give a final volume of $10 \mathrm{~mL}$. The EOEP was mixed into a test tube to give a final concentration in the range of 0.01 to $5 \%(v / v)$. The methodology also included positive and negative controls. The positive control included tubes containing inoculum and MHB medium without EOEP, and the negative control comprised tubes containing EOEP and MHB medium, without inoculum. The test tubes with only MHB medium served as a blank control. After mixing, the test tubes were incubated at $37^{\circ} \mathrm{C}$, except B. cereus was incubated at $30^{\circ} \mathrm{C}$ for $24 \mathrm{~h}$. Survival numbers of tested bacteria were examined using the spread plate method. B. cereus, S. aureus, E. coli, P. aeruginosa and S. Typhimurium were grown on TSA. Listeria spp. was grown on TSAYE and lactic acid bacteria was grown in MRS agar. Then, the agar was incubated at $37^{\circ} \mathrm{C}$, while B. cereus was incubated at $30^{\circ} \mathrm{C}$. All experiments were repeated in triplicate and duplicated in each experiment.

The MIC was defined as the lowest concentration of antimicrobial concentration required to inhibit the visible growth in the test tube. The MBC was defined as the lowest concentration of antimicrobial concentration required to diminish more than $99.9 \%$ (3 Log reduction) of the initial bacterial amount at $24 \mathrm{~h}[46,47]$.

\subsubsection{Time-kill Assay}

The antimicrobial activity of EOEP over time was determined against B. cereus, S. aureus and L. monocytogenes Scott A. This method was modified from Thongson, et al. [48] and Ekkarin, et al. [49]. B. cereus and S. aureus were grown in TSB and L. monocytogenes Scott A was grown in TSBYE for $18 \mathrm{~h}$ and serially diluted into $10 \mathrm{~mL}$ double strength broth media, which was contained in a $125 \mathrm{~mL}$ Erlenmeyer flask. Then, a certain amount of EOEP was added to maintain the concentration at 0 (a positive control), $0.01,0.03,0.05,0.1$ and $0.15 \%(v / v)$. Sterile distilled water was then added to adjust the total volume to $20 \mathrm{~mL}$. The final concentration of the initial cell was $3 \mathrm{Log} C F U / \mathrm{mL}$. All flasks were incubated at $37^{\circ} \mathrm{C}$, except B. cereus, which was incubated at $30^{\circ} \mathrm{C}$ in a shaker at $100 \mathrm{rpm}$ for up to $24 \mathrm{~h}$. Numbers of survivor were taken at $0,1,3,6,9,12,18$ and $24 \mathrm{~h}$ and viable cells were enumerated on agar media. All experiments were repeated in triplicate and duplicated in a single repeat.

\subsection{Determination of Mode of Actions of EOEP on B. cereus Using Synchrotron FTIR Microspectroscopy}

\subsubsection{Synchrotron FTIR Sample Preparation}

B. cereus cells were grown at $30{ }^{\circ} \mathrm{C}$ in TSB medium added with EOEP. The samples were taken immediately after contact with EOEP $(0 \mathrm{~h})$, and then after $6 \mathrm{~h}$ and $12 \mathrm{~h}$. A $5 \mu \mathrm{l}$ aliquot of B. cereus was transferred into a new sterile microtube and centrifuged at 12,000 rpm for $2 \mathrm{~min}$. A pellet was washed twice using sterile $0.85 \% \mathrm{NaCl}$ and DI water. The suspended culture was placed on an IR-transparent 2-mm-thick barium fluoride $\left(\mathrm{BaF}_{2}\right)$ slide. Samples on the slide were dried at room temperature for $2 \mathrm{~h}$ under laminar flow for dehydration. The dried samples on the $\mathrm{BaF}_{2}$ slides were kept in a vacuum and dried before FTIR analysis. The Synchrotron FTIR microspectroscopy was performed at Beamline 4.1 in the Synchrotron Light Research Institute (SLRI, Nakhon Ratchasima, Thailand). The FTIR microspectra were obtained from the wavenumber range of $3000-800 \mathrm{~cm}^{-1}$. In total, 270 spectra (90 spectra per 
replicate) were acquired at room temperature. The measurement was performed in the mapping mode using an aperture size $10 \times 10 \mu \mathrm{m}$ with a spectral resolution of $6 \mathrm{~cm}^{-1}$ and 64 scans co-added. Spectral acquisition and instrument control were performed using an OPUS 6.5 (Bruker, Ettlingen, Germany).

\subsubsection{FTIR Data Analysis}

Before all spectra of $B$. cereus cells were collected each time, background was collected each time. All spectra were nine-point smoothed, normalized, baseline corrected and integrated using the OPUS 6.5 software. A second derivative of the spectrum was calculated using the Savitzky-Golay algorithm and subjected to the multivariate statistical technique of principal component analysis (PCA) by Unscramble X software (Camo Analytics, Oslo, Norway).

\subsection{Statistical Analysis}

The data obtained in this study are expressed as the mean of at least three replicates determined and standard deviation (S.D.). Analysis of variance (ANOVA) was performed using Duncan multiple comparison tests at $p \leq 0.05$ by SPSS version 12.0 (SPSS Inc., Chicago, IL, USA) for Windows.

\section{Conclusions}

Essential oils obtained from the E. pavieana rhizome contain high trans-anethole and estragole content, allowing them to inhibit Gram-positive bacteria associated with ready-to-eat (RTE) foods, namely L. monocytogenes, B. cereus and $S$. aureus. The main active compounds reacted mostly with the cell plasma membrane, causing the DNA/nucleic acid and protein to leak. This study provides the benefit of using EOEP as a natural food preservative in certain liquid foods system.

Author Contributions: All authors contributed to the conception and design of the study; P.N. collected the plant material and performed distillation and data analysis; K.N. and M.J.O.-C. advised on the "Volatile section" for both the methods and discussion; P.N. wrote the first draft of the manuscript; C.R. and K.T. advised on Synchrotron FTIR sample preparation and FTIR data analysis; C.R., K.T., S.T., K.N. and M.J. reviewed and edited the manuscript. All authors have read and agreed to the published version of the manuscript.

Funding: This work was supported by Rajamangala University of Technology Krungtep (UTK) and the International Affairs Division, Kasetsart University.

Acknowledgments: The authors are very grateful for the financial support obtained from Rajamangala University of Technology Krungtep (UTK) and the International Affairs Division, Kasetsart University. We are also grateful to associate Professor Aram Attajadee - an emeritus professor of the Faculty of Agro-Industrial Technology, Rajamangala University of Technology Tawan-ok, Thailand-for plant identification, the Department of Food Science and Technology, Faculty of Agro-Industry, Kasetsart University, and the Department of Food and Nutritional Sciences, University of Reading, United Kingdom, for providing access to the experimental facilities.

Conflicts of Interest: The authors declare no conflict of interest.

\section{References}

1. Poulsen, A.; Phonsena, P. Morphological variation and distribution of the useful ginger, Etlingera pavieana (Zingiberaceae). Nord. J. Bot. 2017, 35, 467-475. [CrossRef]

2. Tachai, S.; Wangkarn, S.; Nuntawong, N. Chemical constituents of the rhizome oils of Etlingera pavieana (Pierre ex Gagnep.) R.M.Sm. Biochem. Syst. Ecol. 2014, 57, 410-415. [CrossRef]

3. Srisook, E.; Palachot, M.; Mankhong, S.; Srisook, K. Anti-inflammatory Effect of Etlingera pavieana (Pierre ex Gagnep.) R.M.Sm. Rhizomal Extract and Its Phenolic Compounds in Lipopolysaccharide-Stimulated Macrophages. Pharm. Mag. 2017, 13 (Suppl. 2), S230-S235. [CrossRef] [PubMed]

4. Naksang, P.; Rachtanapun, C. Effect of sample preparation on antibacterial activity of Etlingera pavieana (Pierre ex Gagnep) R.M.Sm. extracts against foodborne bacteria. In Proceedings of the 53rd Kasetsart University Annual Conference: Innovation for Bio-Health Supplements, Kasetsart University, Bangkok, Thailand, 3-6 February 2015.

5. Srisook, K.; Srisook, E. Pharmacological activities and phytochemicals of Etlingera pavieana (Pierre ex Gagnep) R.M.Sm. IntechOpen 2019, 1-13. [CrossRef] 
6. Morales-Soto, A.; Oruna-Concha, M.J.; Elmore, J.S.; Barrajón-Catalán, E.; Micol, V.; Roldán, C.; Segura-Carretero, A. Volatile profile of Spanish Cistus plants as sources of antimicrobials for industrial applications. Ind. Crop. Prod. 2015, 74, 425-433. [CrossRef]

7. Saoudi, S.; Chammem, N.; Sifaoui, I.; Bouassida-Beji, M.; Jimenez, I.A.; Bazzocchi, I.L.; Silva, S.D.; Hamdi, M.; Bronze, M.R. Influence of Tunisian aromatic plants on the prevention of oxidation in soybean oil under heating and frying conditions. Food Chem. 2016, 212, 503-511. [CrossRef]

8. Vairappan, C.S.; Nagappan, T.; Palaniveloo, K. Essential oil composition, cytotoxic and antibacterial activities of five Etlingera species from Borneo. Nat. Prod. Commun. 2012, 7, 1934578X1200700233. [CrossRef]

9. Abdelmageed, A.H.A.; Faridah, Q.Z.; Nur Amalina, A.; Yaacob, M. The influence of organ and post-harvest drying period on yield and chemical composition of the essential oils of Ethlingera elatior (Zingiberaceae). J. Med. Plants Res. 2011, 5, 3432-3439.

10. Ud-Daula, A.F.M.; Basher, M.A. Genus Etlingera-A review on chemical composition and antimicrobial activity of essential oils. J. Med. Plants Res. 2019, 13, 135-156.

11. Tadthong, S.; Wannakhot, P.; Poolsawat, W.; Athikomkulchai, S.; Ruangrungsi, N. Antimicrobial activities of essential oil from Etlingera punicea rhizome. J. Health Res. 2009, 23, 77-79.

12. Bhuiyan, M.N.I.; Chowdhury, J.U.; Begum, J.; Azim, M.A. Aromatic plants of Bangladesh: Constituents of leaf and rhizome oil of Etlingera linguiforme. Dhaka Univ. J. Sci. 2010, 58, 13-15.

13. Abdelwahab, S.I.; Zaman, F.Q.; Mariod, A.A.; Yaacob, M.; Abdelmageed, A.H.; Khamis, S. Chemical composition, antioxidant and antibacterial properties of the essential oils of Etlingera elatior and Cinnamomum pubescens Kochummen. J Sci Food Agric 2010, 90, 2682-2688. [CrossRef] [PubMed]

14. Mahdavi, B.; Yaacob, W.A.; Din, L.B. Chemical composition, antioxidant, and antibacterial activity of essential oils from Etlingera sayapensis A.D. Poulsen \& Ibrahim. Asian Pac. J. Trop. Med. 2017, 10, 819-826. [PubMed]

15. Wijekoon, M.M.J.O.; Bhat, R.; Karim, A.A.; Fazilah, A. Chemical composition and antimicrobial activity of essential oil and solvent extracts of torch ginger inflorescence (Etlingera elatior Jack.). Int. J. Food Prop. 2013, 16, 1200-1210. [CrossRef]

16. Ud-Daula, A.F.M.S.; Demirci, F.; Abu Salim, K.; Demirci, B.; Lim, L.B.L.; Baser, K.H.C.; Ahmad, N. Chemical composition, antioxidant and antimicrobial activities of essential oils from leaves, aerial stems, basal stems, and rhizomes of Etlingera fimbriobracteata (K.Schum.) R.M.Sm. Ind. Crop. Prod. 2016, 84, 189-198. [CrossRef]

17. Chan, E.W.C.; Lim, Y.Y.; Omar, M. Antioxidant and antibacterial activity of leaves of Etlingera species (Zingiberaceae) in Peninsular Malaysia. Food Chem. 2007, 104, 1586-1593. [CrossRef]

18. Tachai, S.; Nuntawong, N. Uncommon secondary metabolites from Etlingera pavieana rhizomes. Nat. Prod. Res. 2016, 30, 2215-2219. [CrossRef]

19. Chiang, E.C.W.; Yan, L.Y.; Ali, A.Z.M. Composition and antibacterial activity of essential oils from leaves of Etlingera species (Zingiberaceae). Int. J. Adv. Sci. Arts. 2010, 1, 1-12.

20. Susanti, D.; Awang, N.A.; Qaralleh, H.; Sheikh Mohamed, H.I.; Attoumani, N. Antimicrobial activity and chemical composition of essential oil of Malaysian Etlingera elatior (Jack) R.M. Smith flowers. J. Essent. Oil Bear. Plants 2013, 16, 294-299. [CrossRef]

21. Burt, S. Essential oils: Their antibacterial properties and potential applications in foods-a review. Int. J. Food Microbiol. 2004, 94, 223-253. [CrossRef]

22. Ruberto, G.; Baratta, M.T.; Deans, S.G.; Dorman, H.J. Antioxidant and antimicrobial activity of Foeniculum vulgare and Crithmum maritimum essential oils. Planta Med. 2000, 66, 687-693. [CrossRef] [PubMed]

23. Ambrosio, C.; Ikeda, N.; Miano Pastor, A.; Villa, E.; Moreno, A.; Stashenko, E.; Contreras-Castillo, C.; da Gloria, E. Unraveling the selective antibacterial activity and chemical composition of citrus essential oils. Sci. Rep. 2019, 9, 1-13. [CrossRef] [PubMed]

24. Dunn, L.; Davidson, P.M.; Critzer, F. Antimicrobial efficacy of an array of essential oils against lactic acid bacteria. J. Food Sci. 2016, 81. [CrossRef] [PubMed]

25. Ouwehand, A.; Tiihonen, K.; Kettunen, H.; Peuranen, S.; Schulze, H.; Rautonen, N. In vitro effects of essential oils on potential pathogens and beneficial members of the normal microbiota. Vet. Med. 2010, 55, 71-78. [CrossRef]

26. Gutierrez, J.; Barry-Ryan, C.; Bourke, P. The antimicrobial efficacy of plant essential oil combinations and interactions with food ingredients. Int. J. Food Microbiol. 2008, 124, 91-97. [CrossRef]

27. Davidson, P.M. Methods for testing the efficacy of food antimicrobials. Food Technol. 1989, 43, $148-155$. 
28. Karapinar, M.; Esen Aktuğ, Ş. Inhibition of foodborne pathogens by thymol, eugenol, menthol and anethole. Int. J. Food Microbiol. 1987, 4, 161-166. [CrossRef]

29. Song, Y.R.; Choi, M.S.; Choi, G.W.; Park, I.K.; Oh, C.S. Antibacterial activity of cinnamaldehyde and estragole extracted from plant essential oils against Pseudomonas syringae pv. actinidiae causing bacterial canker disease in kiwifruit. Plant Pathol J 2016, 32, 363-370. [CrossRef]

30. Osei-Safo, D.; Addae-Mensah, I.; Garneau, F.-X.; Koumaglo, H. A comparative study of the antimicrobial activity of the leaf essential oils of chemo-varieties of Clausena anisata (Willd.) Hook. f. ex Benth. Ind. Crop. Prod. Ind. Crop. Prod. 2010, 32, 634-638. [CrossRef]

31. Shahat, A.A.; Ibrahim, A.Y.; Hendawy, S.F.; Omer, E.A.; Hammouda, F.M.; Abdel-Rahman, F.H.; Saleh, M.A. Chemical composition, antimicrobial and antioxidant activities of essential oils from organically cultivated fennel cultivars. Molecules 2011, 16, 1366-1377. [CrossRef]

32. Naumann, D. Infrared spectroscopy in microbiology. In Encyclopedia of Analytical Chemistry; Meyers, R.A., Ed.; John Wiley \& Sons: Chichester, UK, 2000; pp. 102-131.

33. Lin, S.F.; Schraft, H.; Griffith, M.W. Identification of Bacillus cereus by Fourier transform infrared spectroscopy (FTIR). J. Food Prot. 1998, 61, 921-923. [CrossRef] [PubMed]

34. Mietke, H.; Beer, W.; Schleif, J.; Schabert, G.; Reissbrodt, R. Differentiation between probiotic and wild-type Bacillus cereus isolates by antibiotic susceptibility test and Fourier transform infrared spectroscopy (FT-IR). Int. J. Food Microbiol. 2010, 140, 57-60. [CrossRef]

35. Movasaghi, Z.; Rehman, S.; ur Rehman, D.I. Fourier transform infrared (FTIR) spectroscopy of biological tissues. Appl. Spectrosc. Rev. 2008, 43, 134-179. [CrossRef]

36. Davis, R.; Mauer, L.J. Fourier transform infrared (FT-IR) spectroscopy: A rapid tool for detection and analysis of foodborne pathogenic bacteria. In Current Research, Technology and Education Topics in Applied Microbiology and Microbial Biotechnology; Mendez-Vilas, A., Ed.; Formatex Research Center: Badajoz, Spain, 2010; pp. 1582-1594.

37. Yu, C.; Irudayaraj, J. Spectroscopic characterization of microorganisms by Fourier transform infrared microspectroscopy. Biopolymers 2005, 77, 368-377. [CrossRef] [PubMed]

38. Paluszkiewicz, C.; Kwiatek, W.M. Analysis of human cancer prostate tissues using FTIR microscopy and SXIXE techniques. Mol. Struct. 2001, 565, 329-334. [CrossRef]

39. Fung, M.F.K.; Senterman, M.K.; Mikhael, N.Z.; Lacelle, S.; Wong, P.T.T. Pressure-tuning Fourier transform infrared spectroscopic study of carcino-genesis in human endometrium. Biospectroscopy 1996, 2, 155-165. [CrossRef]

40. Dovbeshko, G.I.; Gridina, N.Y.; Kruglova, E.B.; Pashchuk, O.P. FTIR spectroscopy studies of nucleic acid damage. Talanta 1997, 53, 233-246. [CrossRef]

41. Wood, B.R.; Quinn, M.A.; Tait, B.; Ashdown, M.; Hislop, T.; Romeo, M.; McNaughton, D. FTIR microspectroscopic study of cell types and potential confounding variables in screening for cervical malignancies. Biospectroscopy 1998, 4, 75-91. [CrossRef]

42. Wood, B.R.; Quinn, M.A.; Burden, F.R.; McNaughton, D. An investigation into FT-IR spectroscopy as a bio-diagnostic tool for cervical cancer. Biospectroscopy 1996, 2, 143-153. [CrossRef]

43. Shetty, G.; Kedall, C.; Shepherd, N.; Stone, N.; Barr, H. Raman spectroscopy: Evaluation of biochemical changes in carcinogenesis of oesophagus. Br. J. Cancer 2006, 94, 1460-1464. [CrossRef]

44. Agarwal, R.; Tandon, P.; Gupta, V.D. Phonon dispersion in poly (dimethylsilane). J. Organomet. Chem. 2006, 691, 2902-2908. [CrossRef]

45. Fukuyama, Y.; Yoshida, S.; Yanagisawa, S.; Shimizu, M. A study on the differences between oral squamous cell carcinomas and normal oral mucosa measured by Fourier transform infrared spectroscopy. Biospectroscopy 1999, 5, 117-126. [CrossRef]

46. Sukmark, T.; Rachtanapun, P.; Rachtanapun, C. Antimicrobial activity of oligomer and polymer chitosan from different sources against foodborne pathogenic bacteria. Kasetsart J. (Nat. Sci.) 2011, 45, 636-643.

47. Delaquis, P.J.; Stanich, K.; Girard, B.; Mazza, G. Antimicrobial activity of individual and mixed fractions of dill, cilantro, coriander and eucalyptus essential oils. Int. J. Food Microbiol. 2002, 74, 101-109. [CrossRef]

48. Thongson, C.; Davidson, P.M.; Mahakarnchanakul, W.; Vibulsresth, P. Antimicrobial effect of Thai spices against Listeria monocytogenes and Salmonella Typhimurium DT104. J. Food Prot. 2005, 68, 2054-2058. [CrossRef] [PubMed] 
49. Ekkarin, P.; Rachtanapun, C.; Wanchaitanawong, P.; Mahakarnchanakul, W. Antimicrobial activity of spice extracts against pathogenic and spoilage microorganisms. Kasetsart J. (Nat. Sci.) 2006, 40, 159-165.

Sample Availability: Samples of the compounds are available from the authors. article distributed under the terms and conditions of the Creative Commons Attribution (CC BY) license (http://creativecommons.org/licenses/by/4.0/). 